\title{
Effects of Albendazole Sulphoxide on Embryonic, Foetal and Placental Parameters in Wistar Rats
}

\author{
Efectos de Albendazol Sulfóxido sobre Parámetros Embrionarios, \\ Fetales y Placentarios en Ratas Wistar
}

Teruel, M.; García, V. \& Catalano, R.

\begin{abstract}
TERUEL, M.; GARCÍA, V. \& CATALANO, R. Effects of albendazole sulphoxide on embryonic, foetal and placental parameters in
\end{abstract} Wistar Rats. Int. J. Morphol., 27(4):1147-1153, 2009.

SUMMARY: The aim of this work was to evaluate the effect of albendazole sulphoxide (ABZSO), administered to Wistar rats during pregnancy on embryonic, foetal and placental parameters. A colpocytological control was performed daily and detection of spermatozoa in the vaginal smear was considered as day 0 of pregnancy. For the preimplantational study, ABZSO (10 mg/kg) was orally administered at day 2 of pregnancy; at day 4 the embryos were collected. For the postimplantational study, ABZSO (10 mg/kg) was orally administered by gavages at day 2, 6 or 10 of pregnancy (G2, G6 and G10 Groups respectively); the control group was administered the same volume of carboxymethylcellulose vehicle used to prepare the drug suspension. Fetuses were obtained from pregnant rats sacrificed on day 20 of gestation. Maternal body weight gains were analyzed using the one-way ANOVA test. Embryonic and foetal variables were analized on a per litter basis by the Kruskal-Wallis test. Skeletal anomalies were analyzed using an $\mathrm{X}^{2}$ test. The significance level accepted was established at $\mathrm{P}<0.05$. In the preimplantational analysis, the cleavage rate was lower in the experimental group (P<0.05). In the postimplantational analysis there were no differences in the net weight increase among females of the different groups (P $>0.05)$. The number of fetuses and the foetal vesicles weight were lower in the G10 group $(\mathrm{P}<0.05)$. This group showed the highest percentage of resorptions $(\mathrm{P}<0.05)$ and fetuses morphologically abnormal. An increase in the number of bones affected in fetuses of G6 and G10 groups was observed. The most common malformations were at vertebral, costal and head level. Weights and placental diameters were lower in the G10 group $(\mathrm{P}<0.05)$. We conclude that ABZSO at the dose used in this study affects the cleavage rate in preimplantational embryo development, without interrupting pregnancy. Furthermore; the developmental toxicity is related to day of administration.

KEY WORDS: Albendazole Sulphoxide; Gestation; Toxicity; Wistar Rats.

\section{INTRODUCTION}

The presence of parasites in farm animals carries important sanitary problems and economical loss. The need of controlling them, has promoted the development of molecules with anthelmintic activity, being benzimidazole a broad-spectrum anthelmintic agent used both in humans and veterinary medicine.

Among the anthelmintic agents, benzimidazoles present a broad spectrum of activity with high effectiveness and safety (Campbell, 1990), however administered during gestation, they have demonstrated teratogenic effects such as external, skeletal and vascular abnormalities (Cristofol et al., 1997; Navarro et al., 1998, 1999; Teruel et al., 2003).

Benzimidazole anthelmintics inhibited the energetic metabolism of parasites and bound with tubulin inhibiting its polymerization to microtubules thus interfering with mitotic activity (Lacey, 1988; 1990). Several studies suggest that the capacity of benzimidazolic drugs to bind with the tubulin of cellules is responsible for the toxic effects observed during the gestation (Delatour \& Parish, 1986; Piscopo \& Smoak, 1997).

Albendazole (ABZ) is an anthelmintic agent belonging to the benzimidazole class and its efficacy is attributed to its active (ABZSO) metabolite, owing to its higher systemic availability compared to ABZ (Delatour et al., 1984). It's well known that the fetal membranes permeability changes during gestation and there are differences in the permeability to drugs at the first third of pregnancy compared to the last phase of it. 
Diverse alterations have been observed on pregnancy in different species induced by anthelmintic drugs, and could be due to different experimental models, while in some works the drug was administered punctually at a determined day of pregnancy, in others, periods more extensive were used; furthermore pregnancy is a dynamic process with changes in different female tissues, organs and systems that modify the kinetics of the drug.

While the effects of ABZSO at post implantation period of pregnancy are known, limited data on possible effects on earlier development are available. For this reason, ABZSO was chosen as a model metabolite for a study in vivo to obtain information about the possible embryonic, foetal and placental alterations induced by this anthelmintic drug after its administration at different gestational times to pregnant Wistar rats.

\section{MATERIAL AND METHOD}

Wistar rats with a mean body weight of $264.0 \pm 27.4 \mathrm{~g}$ from our own breeding colony were allotted in plastic boxes, and had free access to tap water. During the adaptation period, the animals were maintained in groups of 4 animals each with periods of 14 hours of light and 10 hours of darkness and were used according to the Animal Welfare Act (Facultad de Ciencias Veterinarias, Universidad Nacional del Centro de la Provincia de Buenos Aires).

Females were allowed to mate with mature males (2:1) and a colpocytological control was performed daily. Detection of spermatozoa in the vaginal smear was considered as day 0 of pregnancy.

To analyze the effect of ABZSO on preimplantational development, eleven pregnant rats were randomly assigned to two groups. The experimental group $(n=5)$ was administered ABZSO (racemic mixture, batch number 60011, Microsules Argentina S.A.) orally by gavages at a dose of $10 \mathrm{mg} / \mathrm{kg}$ body weight on day 2 of pregnancy (ABZSO 2 Group); the control group ( $\mathrm{n}=6$ ) was administered the same volume of carboxymethylcellulose vehicle used to prepare the drug suspension.

To analyze the effect of ABZSO on post implantation development, twenty pregnant rats were randomly assigned to four groups of five animals each. ABZSO (racemic mixture, batch number 6-0011, Microsules Argentina S.A.) was administered orally by gavages at a dose of $10 \mathrm{mg} / \mathrm{kg}$ body weight on day 2, 6 or 10 of pregnancy (G2, G6 and G10 Group respectively); the control group was administered the same volume of carboxymethylcellulose vehicle used to prepare the drug suspension.

Preimplantational embryos were recovered in Ham F10 (Gibco BRL, Life Technologies NY, USA) supplemented with $0.4 \%$ of BSA (Sigma Chemical Company, St. Louis, MO, USA) using a 30-g needle on a $1 \mathrm{cc}$ syringe from uteri of pregnant females killed by inhalation of an overdose of anesthetic (ethylic ether) on day 4 of pregnancy.

Fetuses were obtained from pregnant rats sacrificed at day 20 of gestation by an inhalatory anesthetic (ethylic ether) overdose. The reproductive tract was collected as described by Barrow (1990). The preimplantational development was evaluated considering the recollection rate determined at the embryos collection time, by the relation between the number of corpus luteum and the number of collected embryos per cent; the total number of collected embryos per female; the percentage of embryos morphologically normal determined by the relation between the number of normal embryos and the total collected embryos per cent (embryos morphologically normal were considered those with intact pellucida zone and with no asymmetry, blastomeres lost of the inner cell mass, with cytoplasm granulations or irregular shapes); the cleavage rate determined by counting the nuclei according to Tarkowski (1966) method and the differentiation rate determined by the relation between the number of blastocyst and the total embryos collected per cent; the blastocysts were classified to early blastocysts, blastocysts, expanded blastocysts and protruded blastocysts.

Maternal net weight increase was considered as the weight at day 20 of gestation minus the gestational uterus weight and the weight at day 1 of gestation. Resorption rate was calculated for each female as total resorptions observed divided by the number of implantation sites observed per cent; the presence of resorptions was considered when implantation sites or placental remains were macroscopically observed.

General aspect; body weight; body measures (greatest length: GL; crown-rump length: CRL; head length: HL); proportions of head, stalk, limbs; presence, position and proportions of cephalic structures; position of limbs; presence and number of fingers; normality of the genital area; presence of anus and aspect of the tail were determined. The percentage of fetuses with skeletal alterations was examined by the Dawson alizarin-red staining technique (Dawson technique modified by Barrow). Immediately after the opening of foetal vesicles, the weight, diameter and qualitative characteristics of placentas were recorded. 
The embryonic collection rate, the percentage of differentiation, the percentage of embryos morphologically normal, the total number of collected embryos per female; and the cleavage rate were analyzed on a per litter basis using the Kruskal-Wallis test.

Maternal body weight gains were analyzed using the one-way ANOVA test. The number of implantation sites, total fetus, the resorptions rate, the percentage of live fetuses, the weight of foetal vesicles and fetuses, measurements of placentas and fetuses and percentages of fetuses morphologically normal (presence, position and proportions of anatomic structures) were analyzed on a per litter basis using the Kruskal-Wallis test. Differences in skeletal anomalies were analyzed using an $\mathrm{X}^{2}$ test. The significance level accepted for differences among groups was established at $\mathrm{P}<0.05$.

\section{RESULTS}

No statistically significant differences were found in embryonic collection rate nor in the number of embryos collected by female after the administration of $10 \mathrm{mg} / \mathrm{kg} /$ day of ABZSO on day 2 of pregnancy compared to the untreated control group $(72.4 \pm 21.5 \%$ vs. $76.0 \pm 12.7 \%$ and $10.2 \pm 20.3$ vs. $10.0 \pm 1.4$, respectively; $\mathrm{P}>0.05$ ). Experimental and control embryos showed normal morphological characteristics no matter stadium of development (morulae or blastocyst).
The cleavage rate for the ABZSO 2 Group was significantly lower compared to the control group $(33.4 \pm 16.4$ cells vs. $45.6 \pm 6.4$ cells, respectively; $\mathrm{P}<0.05$ ). In embryos of ABZSO 2 and control Groups, the differentiation rate was similar ( $\mathrm{P}>0.05$; Table I). The proportion of early blastocysts, blastocysts, expanded blastocysts and protruded blastocysts did not show differences between groups ( $\mathrm{P}>0.05$; Table I).

There were no differences in the net weight increase among females of the different groups $(61.36 \pm 22.8 \mathrm{~g} ; 48.32$ $\pm 13.9 \mathrm{~g} ; 67.44 \pm 21.5 \mathrm{~g}$ and $67.44 \pm 21.5 \mathrm{~g}$ for control, G2, G6 and G10 Group respectively; $P>0.05$ ). The number of implantation sites was not affected by ABZSO administered on different days of pregnancy ( $\mathrm{P}>0.05$; Table II), however, the number of fetuses resulted lower in the G10 group $(\mathrm{P}<0.05$; Table II).

The percentage of resorption for the G10 group was significantly higher $(\mathrm{P}<0.05$; Table II). With reference to foetal viability, there were no differences between live fetuses from experimental and control groups $(\mathrm{P}>0.05)$. The foetal vesicles weight in G10 group was significantly lower than in untreated, G2 and G6 groups ( $\mathrm{P}<0.05$; Table III). The foetal weight between the control, G2 and G6 groups did not show significant differences $(\mathrm{P}>0.05)$. The values corresponding to day 10 of treatment were not included in the statistical analysis since only one female had fetuses (Table III).

No statistically significant differences were found in the greatest length, the crown-rump length and the head length between control, G2 and G6 groups $(\mathrm{P}>0.05)$. The values

Table I. Blastocyst differentiation in Wistar rats treated with albendazole sulphoxide (ABZSO) on day 2 of pregnancy.

\begin{tabular}{cccccc} 
Group & $\begin{array}{c}\text { Differentiation } \\
\text { rate }(\%)\end{array}$ & Early blastocysts & Blastocysts & Expanded & Protrudes \\
& & & & blastocysts & blastocysts \\
Control & $93.3 \pm 10.5$ & $5.7 \pm 10.1$ & $56.0 \pm 22.0$ & $31.2 \pm 26.5$ & $7.1 \pm 5.9$ \\
\hline ABZSO 2 & $98.0 \pm 4.5$ & $10.2 \pm 10.0$ & $38.9 \pm 30.5$ & $36 . \pm 40.0$ & $14.3 \pm 20.1$
\end{tabular}

Values are presented as mean $\pm \mathrm{SD}$.

Table II. Effect of albendazole sulphoxide (ABZSO) administered on different days of pregnancy on postimplantational development in Wistar rats.

\begin{tabular}{ccccc} 
Foetal variable & \multicolumn{4}{c}{ Days of ABZSO administration } \\
& Control group & 2 (G2 group) & 6 (G6 group) & 10 (G10 group) \\
Number of implantation sites per female & $13.4 \pm 2.61$ & $11.4 \pm 1.34$ & $13.8 \pm 2.59$ & $11.8 \pm 5.02$ \\
Number of fetuses per female & $11.8 \pm 2.17 \mathrm{a}$ & $10.8 \pm 1.79 \mathrm{a}$ & $12.6 \pm 1.82 \mathrm{a}$ & $2.0 \pm 4.47 \mathrm{~b}$ \\
Rersorption rate per female $(\%)$ & $15.04 \pm 20.10 \mathrm{a}$ & $5.55 \pm 7.85 \mathrm{a}$ & $6.40 \pm 9.14 \mathrm{a}$ & $81.82 \pm 40.66 \mathrm{~b}$
\end{tabular}

Different letters within a file indicate statistical differences at $\mathrm{P}<0.05$. Values are presented as mean $\pm \mathrm{SD}$. 
corresponding to day 10 of treatment were not included in the statistical analysis since only one female had fetuses (Table III).

The examination of fetuses of the G2, G6 and control groups revealed no macroscopic alterations. In the G10 group, the fetuses from the only female that completed the gestation period, showed tail agenesis (30\%), short tail (20\%) and opening of cranial cavity (100\%). The skeletal analysis showed an increase in the number of bones affected in fetuses of G6 and G10 groups. The totality of fetuses of G10 group showed skeletal anomalies. The most common malformations were at vertebral, costal, metacarpal and head level (Fig. 1). Thoracic vertebral body agenesis, lack of fusion of vertebral bodies and arches, lordosis, cifosis, agenesis and fusion of several ribs, and lack or minor ossification in bones of cranium and face were observed.

The percentages of fetuses presenting reduction in ossification process of different bones are shown in Table IV. The qualitative analysis of placentas showed that, in ABZSO-treated groups, placentas had a whitish halo with a sanguinolent centre $(36.36 \%$ for the $\mathrm{G} 2$ group, $61.01 \%$ for the G6 group and $100 \%$ for placentas of female corresponding to G10 group). The last placentas showed moreover, a delicate pink tonality, characteristic not observed in placentas of control group.

The quantitative analysis of placentas showed that, in G10 groups, placentas had smaller weights and diameter compared to those from G2, G6 and the untreated control group $(\mathrm{P}<0.05$; Table $\mathrm{V})$.

Table III. Effect of albendazole sulphoxide (ABZSO) administered on different days of pregnancy on foetal parameters in Wistar rats.

\begin{tabular}{|c|c|c|c|c|}
\hline \multirow{2}{*}{$\begin{array}{c}\text { Foetal } \\
\text { variable }\end{array}$} & \multicolumn{4}{|c|}{ Days of ABZSO administration } \\
\hline & Control group & 2 (G2 group) & 6 (G6 group) & 10 (G10 group) \\
\hline Foetal vesicles weight (g) & $4.09 \pm 0.24 \mathrm{a}$ & $4.06 \pm 0.29 \mathrm{a}$ & $4.19 \pm 0.26 \mathrm{a}$ & $0.96 \pm 1.62 b$ \\
\hline Foetal weight (g) & $2.52 \pm 0.24$ & $2.52 \pm 0.17$ & $2.66 \pm 0.21$ & $1.85 \pm 0.0 *$ \\
\hline $\mathrm{GL}(\mathrm{cm})$ & $2.92 \pm 0.15$ & $2.96 \pm 0.19$ & $3.00 \pm 0.09$ & $2.60 \pm 0.0 *$ \\
\hline $\mathrm{CRL}(\mathrm{cm})$ & $2.31 \pm 0.11$ & $2.27 \pm 0.06$ & $2.43 \pm 0.11$ & $2.08 \pm 0.0 *$ \\
\hline $\mathrm{HL}(\mathrm{cm})$ & $1.21 \pm 0.03$ & $1.22 \pm 0.02$ & $1.24 \pm 0.03$ & $1.10 \pm 0.0 *$ \\
\hline
\end{tabular}

GL: greatest length; CRL: crown-rump length; HL: head length. Different letters within a file indicate statistical differences at $\mathrm{P}<0.05$. Values are presented as mean $\pm \mathrm{SD}$. * The values corresponding to day 10 of pregnancy are not included in the statistical analysis because only one female rat presented fetuses.

Table IV. Effect of albendazole sulphoxide (ABZSO) administered on different days of pregnancy on the percentage of fetuses showing alterations in skeletal morphology.

\begin{tabular}{lcccc}
\multicolumn{1}{c}{ Skeletal alterations } & \multicolumn{3}{c}{ Days of ABZSO administration } \\
\cline { 2 - 5 } & Control group & 2 (G2 group) & 6 (G6 group) & 10 (G10 group) \\
Fetuses with skeletal alterations & $16.7 \mathrm{a}$ & $20.0 \mathrm{a}$ & $61.1 \mathrm{~b}$ & $100.0 \mathrm{c}$ \\
Alterations in ribs & $\mathrm{N} / \mathrm{O}$ & $\mathrm{N} / \mathrm{O}$ & $\mathrm{N} / \mathrm{O}$ & 100.0 \\
Alterations in cranium & $8.3 \mathrm{a}$ & $10.0 \mathrm{a}$ & $58.3 \mathrm{~b}$ & $100.0 \mathrm{c}$ \\
Alterations in face & $\mathrm{N} / \mathrm{O}$ & $\mathrm{N} / \mathrm{O}$ & $11.1 \mathrm{a}$ & $77.8 \mathrm{~b}$ \\
Alterations in hip & $13.9 \mathrm{ab}$ & $13.3 \mathrm{ab}$ & $8.3 \mathrm{a}$ & $44.4 \mathrm{~b}$ \\
Alterations in metacarpal & $5.6 \mathrm{a}$ & $\mathrm{N} / \mathrm{O}$ & $19.4 \mathrm{a}$ & $22.2 \mathrm{a}$
\end{tabular}

Different letters within a file indicate statistical differences at $\mathrm{P}<0.05$. N/O: not observed.

Table V. Mean placental diameter and weight in Wistar rats treated orally with albendazole sulphoxide (ABZSO) on different days of pregnancy.

\begin{tabular}{lcccc}
\multirow{2}{*}{ Placental variable } & \multicolumn{3}{c}{ Days of ABZSO administration } \\
\cline { 2 - 5 } & Control group & 2 (G2 group) & 6 (G6 group) & 10 (G10 group) \\
Diameter $(\mathrm{cm})$ & $0.77 \pm 0.06 \mathrm{a}$ & $0.76 \pm 0.08 \mathrm{a}$ & $0.76 \pm 0.05 \mathrm{a}$ & $0.26 \pm 0.22 \mathrm{~b}$ \\
Weight $(\mathrm{g})$ & $1.31 \pm 0.03 \mathrm{a}$ & $1.40 \pm 0.09 \mathrm{a}$ & $1.34 \pm 0.05 \mathrm{a}$ & $0.80 \pm 0.28 \mathrm{~b}$
\end{tabular}

Different letters within a file indicate statistical differences at $\mathrm{P}<0.05$. Values are presented as mean $\pm \mathrm{SD}$. 

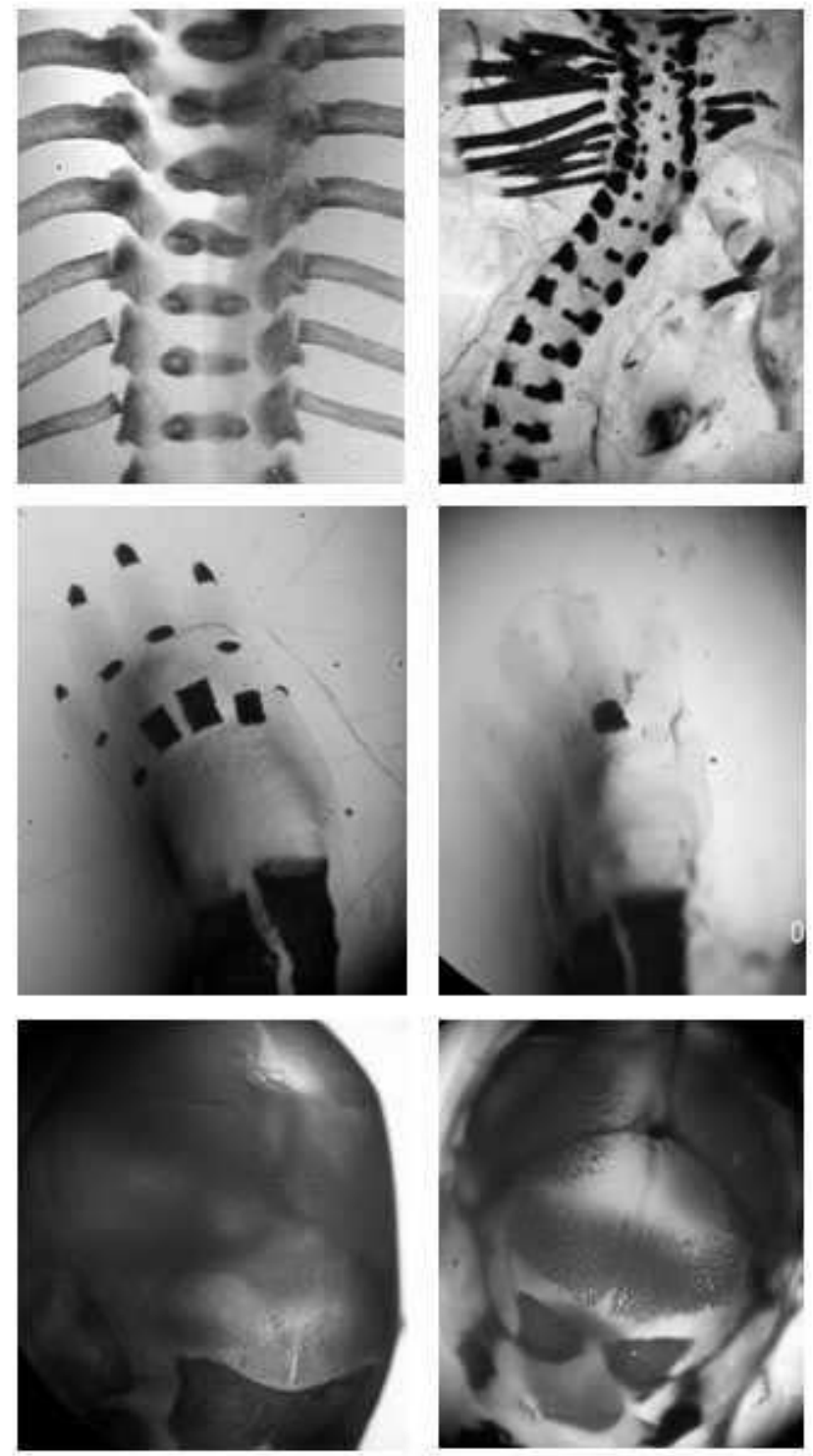

Fig. 1. Skeletal analysis of 20-day-old fetuses recovered from untreated and albendazole sulphoxide treated rats on day 10 of pregnancy. Left column: fetus of untreated control group. Right column: fetus from the G10 group with low ossification process of the ribs, vertebrae, head and metacarpal bones.

\section{DISCUSSION}

Different studies have shown teratogenic effects of the anthelmintic benzimidazoles (Delatour et al.; Cristofol et al., 1995; Navarro et al., 1998; Teruel et al.). The teratogenic activity of $\mathrm{ABZ}$ in vivo is attributed to its active albendazole sulphoxide (ABZSO) metabolite which has the capacity of reaching the embryos in elevated concentrations (Cristofol et al., 1995, 1997; Capece et al., 2003).
The results of this study suggest that the displacement of embryos from oviducts to the uteri, and the morphological embryonic changes before reaching the morulae and blastocyst stadium were not modified by ABZSO. These results agree with Piscopo \& Smoak that showed no effect of ABZSO on in vitro rat embryo development. However, the cleavage rate was significantly lower for embryos collected from females administered with ABZSO at day 2 of pregnancy. As in present study the capacity of cellular division has been altered by ABZSO in vitro (Piscopo \& Smoak). These results suggest that ABZSO affects the cleavage rate as much as in vivo or in vitro assay, probably due to the fact that the embryos are in cleavage during days 2 to 3 of pregnancy (Hebel \& Stromberg, 1986), or to ABZSO binding with tubulin and inhibiting its polymerization to microtubules thus interfering with mitotic activity (Lacey \& Watson, 1985).

In postimplantational development, the effect of ABZSO was affected by de gestation time at which the drug was administered. The anomalies and resorptions observed in this study when the drug was administered at day 10 of pregnancy suggest that ABZSO crosses the placental barrier in agreement with research in ovine (Cristofol et al., 1997) and rats (Capece et al., 2001). These findings are consistent with those of other studies that showed anomalies and resorptions when the drug was administered on a determined day or for a long period during gestation time (Capece et al., 2001; Teruel et al.; Carrara Moreti et al., 2005).

The effects of ABZSO on foetal skeletal development observed in the present study are in agreement with those described by different researchers (Mantovani et al., 1995; Capece et al., 2003; Teruel et al.). The low ossification process observed in bones from both endochondral and intramembranous ossification suggest that ABZSO affects particularly the ossification process independently of the origin.

Probably, significant effects observed when administering ABZSO on day 10 of gestation can be related to the fact that, during days 9 and 10 of the rat embryogenesis, the mesoderm changes drastically. The extra embryonic mesoderm differentiation helps with placental vascularization (Ellington, 1985), likewise, the intraembryonic mesoderm extends on each side of the notochord plate, specifically the beginning of somite formation takes place at the end of day 9 or during day 10. The formation of the intraembryonic mesoderm and its differentiation in regions is fundamental for the formation of cartilaginous and membranous structures that will be the foundations for the skeletal system (Smith \& Tuan, 1996; Sato et al., 2002; Pownall et al., 2002). The cranial malformations observed in this work could be related to the 
fact that the differentiation of neural crests occurs at this step of development (Jiang et al., 2002).

In this research, skeletal anomalies were found in fetuses from females treated with ABSZO at day 6 of pregnancy. These results suggest that this drug affects the trofectoderm and thus the ectoplacental cone with the posterior abnormal development of placenta (Tachi et al., 1970). A high percentage of placentas from females administered ABZSO at day 6 of pregnancy showed a sanguinolent centre. It can be speculated that, although no changes were observed in diameter and weight of placentas, the qualitative changes could be responsible for a lower sanguineous flux and therefore for the anomalies observed.

About the administration of ABZSO at day 2 of pregnancy, though the number of cells per embryos was lower than the number of embryo cells from non treated females, the fetuses at term of pregnancy did not show anomalies; probably the capacity of regulation and the evolutionary potentiality of blastomeres in early steps of development permit the continuous normal development (Pierce et al., 1988; Sakkas \& Vassalli, 2003).

We conclude that ABZSO at the dose used in this study affects the cleavage rate in preimplantational embryo development, without interrupting pregnancy. Furthermore, the developmental toxicity is related to day of pregnancy administration with major effects at day 10.

However, further research is required to confirm these results and understand the mechanisms involved on the development of embryonic, placental and foetal alterations induced by the ABZSO administered during the gestation.

TERUEL, M.; GARCÍA, V. \& CATALANO, R. Efectos de albendazol sulfóxido sobre parámetros embrionarios, fetales y placentarios en ratas Wistar. Int. J. Morphol., 27(4):1147-1153, 2009.

RESUMEN: El objetivo de este trabajo fue caracterizar los efectos de albendazol sulfóxido (ABZSO) durante la gestación de ratas Wistar, sobre parámetros embrionarios, fetales y placentarios. Se efectuó colpocitología diaria de las hembras considerándose día 0 de gestación el día de aparición de espermatozoides en vagina. Estudio preimplantacional: ABZSO (10 mg/kg) fue dosificado oralmente el día 2 de gestación; el día 4 de gestación se realizó la recolección de embriones. Estudio post-implantacional: ABZSO (10 mg/kg) fue dosificado oralmente los días 2, 6 ó 10 de gestación (Grupos G2, G6 y G10, respectivamente). Hembras controles recibieron carboximetilcelulosa, vehículo usado para solubilizar la droga. Las hembras fueron sacrificadas al día 20 de gestación. Variables embrionarias y fetales fueron analizadas sobre la base de las camadas mediante test de Kruskal-Wallis; ganancia de peso de las madres por ANOVA y porcentaje de fetos con alteraciones esqueléticas mediante $\mathrm{X}^{2}$. Estudio preimplantacional: la tasa de recolección embrionaria, el número de embriones recolectados y el porcentaje de diferenciación fueron similares entre grupos $(\mathrm{P}>0,05)$. La velocidad de clivaje fue menor en el grupo experimental $(\mathrm{P}<0,05)$. Estudio post-implantacional: la ganancia de peso de las madres no difirió entre grupos $(\mathrm{P}>0,05)$, el número de fetos y el peso de las vesículas fetales fueron menores en el grupo $\mathrm{G} 10(\mathrm{P}<0,05)$. Los porcentajes de reabsorciones y de fetos con características morfológicas anormales fueron mayores en el grupo G10 ( $\mathrm{P}<0,05)$. Las alteraciones esqueléticas fueron mayores en los grupos G6 y G10 ( $<<0,05)$ observándose con mayor frecuencia en vértebras, costillas y cabeza. Pesos y diámetros placentarios fueron menores en el grupo G10 ( $<<0,05)$. Se concluye que, bajo las condiciones del presente estudio, el ABZSO administrado en la etapa preimplantacional afecta la velocidad de clivaje sin detener la gestación mientras que su efecto en el desarrollo post-implantacional depende del tiempo de gestación en que es administrado.

PALABRAS CLAVE: Albendazol sulfóxido; Gestación; Toxicidad; Ratas Wistar.

\section{REFERENCES}

Barrow, P. Technical procedures in Reproduction Toxicology. London, Royal Soc. Med. Serv., 1990. p.55.

Campbell, W. C. Benzimidazole: veterinary uses. Parasitol. Today., 6:130-3, 1990.

Capece, B. P. Caracterización farmacológica del albendazol sulfóxido y de sus enantiómeros en ovejas y ratas. Tesis Doctoral, Universidad Autónoma de Barcelona, 2001.

Capece, B. P.; Navarro, M.; Arcalis, T.; Castells, G.; Toribio,
L.; Perez, F.; Carretero, A.; Ruberte, J.; Arboix, M. \& Cristofol, C. Albendazole sulphoxide enantiomers in pregnant rats' embryo concentrations and developmental toxicity. Vet. J., 165:266-75, 2003.

Carrara Moreti, D.; Lopes, R.; Vinha, D.; Sala, M.; Semprini, M. \& Friedrichi, M. Efectos del albendazol en el hígado de feto de rata. Estudio morfológico y morfométrico. Int. J. Morphol., 23:111-20, 2005.

Cristofol, C.; Carretero, A.; Fernández, M.; Navarro, M.; 
Sautet, J.; Ruberte, J. \& Arboix, M. Transplacental transport of netobimin metabolites in ewes. Eur. J. Drug Metab. Pharmacokin., 20:167-71, 1995.

Cristofol, C.; Navarro, M.; Franquelo, C.; Valladares, J. P.; Carretero, A.; Ruberte, J. \& Arboix, M. Disposition of netobimin, albendazole and its metabolites in the pregnant rat: Developmental Toxicity. Toxicol. Appl. Pharmacol., 144:56-61, 1997.

Delatour, P.; Garnier, F.; Benoit, E. \& Longin, C. A correlation of toxicity of albendazole and oxfendazole with their free metabolites and bound residues. J. Vet. Pharmacol. Ther., 7:139-45, 1984.

Delatour, P. \& Parish, R. Benzimidazole anthelmintics and related compounds: Toxicity and evaluation of residues. In: Drug Residues in Animals. Rico, A. G. (Ed). New York, Academic Press, 1986. pp.175-203.

Ellington, S. A morphological study of the development of the allantoids of rat embryos in vivo. J. Anat., 142:1-11, 1985.

Hebel, R. \& Stromberg, M. Anatomy and Embryology of the Laboratory Rat. Worthsee: Bio. Med. Verlag, 1986. p.270.

Jiang, X.; Iseki, S.; Maxson, R.; Sucov, H. \& Morriss-Kay, G. Tissue origins and interactions in the mammalian skull vault. Dev. Biol., 241:106-16, 2002.

Lacey, E. \& Watson, T. Structure-activity relationships of benzimidazole carbamates as inhibitors of mammalian tubulin in vitro. Biochem. Pharmacol., 34:1073-7, 1985.

Lacey, E. The role of the cytoskelestal protein, tubulin, in the mode of action and mechanism of drug resistance to benzimidazoles. Internat. J. Parasitol., 18:885-936, 1988.

Lacey, E. Mode of action of benzimidazoles. Parasitol. Today, 6:112-4, 1990.

Mantovani, A.; Macri, C.; Ricciardi, C. \& Stazi, A. Histological alterations in gestational day 13 rat embryos from albendazole-treated dams. Cong. Anom., 35:45566, 1995.

Navarro, M.; Cristofol, C.; Carretero, M.; Arboix, M. \& Ruberte, J. Anthelmintic induced congenital malformations in sheep embryos using Netobimin. Vet. Rec., 142:86-90, 1998.
Navarro, M.; Canut, L.; Carretero, A.; Cristofol, C.; PérezAparicio, F.; Arboix, M. \& Ruberte, J. Developmental toxicity in rat fetuses exposed to benzimidazole netobimin. Reprod Toxicol., 13:295-02, 1999.

Pierce, G.; Arechaga, J.; Muro, C. \& Wells, R. Differentiation of ICM cells into trophectoderm. Am. J. Pathol., 132:35664, 1988.

Piscopo, S. \& Smoak, I. Comparison of effects of albendazole sulfoxide on in vitro produced bovine embryos and rats embryos. Am. J. Vet. Res., 58:1038-42, 1997.

Pownall, M.; Gustafsson, M. \& Emerson, P. Myogenic regulatory factors and the specification of muscle progenitors in vertebrate embryos. Annu. Rev. Cell. Dev. Biol., 18:747-83, 2002.

Sakkas, D. \& Vassalli, J. The preimplantation embryo: development and experimental manipulation. In: Reproductive Health, Geneva Foundation for Medical Education and Research. Disponible en: www.gfmer.ch, 2003.

Sato, Y.; Yasuda, K. \& Takahasy, Y. Morphological boundary forms by a novel inductive event mediated by LunaticFringe and Notch during somatic segmentation. Development, 129:3633-44, 2002.

Smith, C. \& Tuan, R. Functional involvement of Pax-I in somite development: Somite dismorphogenesis in chick embryos treated with Pax-I paired box antisense oligonucleotide. Teratology, 52:333-45, 1996.

Tachi, S.; Tachi, C. \& Lindner, H. Ultrastructural features of blastocyst attachment and trophoblastic invasion in the rat. J. Reprod. Fertil., 21:37-56, 1970.

Tarkowski, A. An air drying methods for chromosomal preparations. Cytogenetics, 5:394-400, 1966.

Teruel, M.; Felipe, A.; Solana, H.; Sallovitz, J. \& Lanusse, C. Placental and fetal toxicity of albendazole sulphoxide in Wistar rats. Vet. Hum. Toxicol., 3:131-6, 2003.

Correspondence to:

M. Teruel

Áreas de Embriología y Reproducción.

Facultad de Ciencias Veterinarias. UNCPBA. Tandil ARGENTINA

Email: mteruel@vet.unicen.edu.ar

Received: 28-07-2009 Accepted: 21-09-2009 
